\title{
Teachers' Views on the Priorities of Effective School Management
}

\author{
S. Anastasiou \\ Assistant Professor, \\ Faculty of Social Sciences, \\ University of Ioannina, Greece

\section{Garametsi} \\ M.Ed., Hellenic Open University, \\ Greece
}

\section{Doi: 10.36941/jesr-2020-0oo1}

\begin{abstract}
The aim of the present study was to investigate teachers' views on the priorities of effective school management. The possible variability of teachers' views in relation to age and work experience was also investigated. For this purpose, research was carried out in Secondary Public and Private Education schools of Ioannina, the capital city and the largest in the Epirus Prefecture, North-West part of Greece. Over 300 questionnaires were distributed to 32 Secondary Education Schools and 165 completed questionnaires were collected (return rate 54.99\%). Teachers were asked to indicate their views on the priorities which should be set for effective School Management. Teachers pointed as most important priorities team work and collaboration with the Principal and their pupils (56\%) whereas as least selected priority (24.4\%) they pointed their participation in helping pupils to get a job. Compared to Public Schools, teachers working in Private Schools gave increased priority in: pupils' performance, raising teachers' aspirations for their pupils, teachers' job satisfaction, team work, collaboration with the Principal, parental involvement-collaboration between teachers and parents and school environment. The results indicate a significant variability on teachers' age and work experience regarding their priorities for effective school management. This variability highlights the importance of focusing on teachers' attitudes for a successful implementation of effective human resources and school management.
\end{abstract}

Keywords: Effective school management, teachers, human resources management, Greece

\section{Introduction}

Teaching profession over the last decade in Greece, has been characterized by a dramatic decline in recruitment and earnings. During this period, questions have been raised regarding the performance of the country's educational system in alignment with the global debate on the goals of an effective education policy (Levin \& Belfield, 2015).

The concept of effectiveness is linked and often confused with the concept of efficiency. A school unit may be effective while at the same time another school may be less efficient than expected in terms of a specific outcome. Schools' efficiency and performance is connected with a number of parameters like: school leader's abilities, teachers, curriculum, work conditions, effective school and 
parental cooperation (Edmonds, 1979).

School outputs should be evaluated in view of their inputs and the regional social and economic conditions. Nevertheless, in times of economic crisis and austerity measures, there is concern about the optimal allocation of funding to public spending, including education spending (Aparicio et al., 2018) with school units having to optimally utilize their available resources. This is not an easy task. School principals have limited choices in terms of resources and they have to make decisions and prioritize their implementation according to the needs of their school unit.

A set of schools' priorities can be established at national, regional or school unit level and goals can vary according to cultural, political, social, economic and technological parameters. At national or regional level, decisions on the strategic goals aligning to an effective educational system are established with school leaders and teachers having to implement these goals.

School leaders set priorities and allocated time and resources on particular features which require attention for ensuring the optimal operation of an effective school while at the same time school leaders and policy makers face the "unresolved" question on what makes one school more effective than another.

This question requires first to tackle a historical debate on what constitutes school effectiveness, a confounding area of inquiry, with academic and political implications. The debate goes on for decades with policy makers facing society's challenging and changing conditions and requirements (Rutter \& Maughan, 2002; Gill et al., 2004; Rawolle et al., 2016).

Furthermore, school leaders' priorities may be shaped according to personality traits and/or particular features/peculiarities of their school units. For example, personality traits can have a significant effect on some school outcomes according to their leader's priorities (Dös\& Savas, 2015; Li et al., 2016) while in the case of a school with a high dropout rate, its leader may give priority to this specific issue rather on focusing on another priority or desirable outcome (Freeman \& Simonsen, 2015).

In addition to possible differences in the priorities of school leaders according to personality traits and school unit peculiarities, different expectations from the society and policy makers can contribute in shaping educational management priorities. For example, governments set the strategic priorities for their educational system (Benavot, 2015; Moss, 2017) with policy makers taking decisions in terms of economic efficiency (Stergiou et al., 2018) whereas parents may evaluate a school unit's effectiveness according to its academic achievements (DeAngelis, 2018).

A balanced judgment on school effectiveness requires the consideration of several parameters which may have a significant effect on school outcomes irrespective of background variables such as neighbourhood social and economics features (Morrissey \& Vinopal, 2018). In fact, effective schools can be viewed as the result of internal and external school variables, including teach er expectations, leadership, educational goals, culture of change, innovation and student achievemen t (Wajdi et al., 2018).

School leadership has a significant role in optimising the outcomes of schools' inputs, maximising the potential of all resources according the goals and settings of effective school management (Nathanaili, 2016; Koutouzis \& Malliara, 2017).

In addition to the leading role of school principals, there is a plethora of evidence to suggest that teachers can have a key role in school effectiveness with initiatives and innovations targeting to inspire and improve pupils' attitudes and academic achievements (Emo, 2015; Gunawan \& Shieh, 2016; Tastan et al., 2018). Teachers' attitudes and background may vary according to age and work experience (Fetters et al., 2002; Broström et al., 2015) creating another challenge for school decision making processes.

Teachers' views on what constitutes effective school leadership and priorities is of paramount importance for management objectives and decision-making processes.

The purpose of this work was to investigate Secondary Education School teachers' views in Greece on their priorities of effective school management. The possible variability of teachers' views in relation to age and work experience was also investigated. 


\section{Methodology}

The research was carried out in Secondary Education Schools of Ioannina, the capital city and the largest in the Epirus Prefecture, North-West part of Greece.

Over 300 questionnaires were distributed to 32 schools and 165 completed were collected (return rate 54.99\%) from teachers working in Public $(n=133)$ and Private Schools $(n=32)$.

Teachers were asked to indicate on a Likert five- point scale (1. Strongly disagree, 2. Somewhat disagree, 3. Neither agree nor disagree, 4. Agree, 5. Strongly agree) their views on the priorities of nine School Management goals which included: 1. Pupils' Academic Performance, 2. Employing innovative teaching approaches, 3. Raise Teachers' aspirations for all of their pupils, 4. Teachers' Job satisfaction, 5. Teachers' team work- collaboration with their Principal, 6. Collaboration with pupils, 7. Parental involvement-collaboration between teachers and parents, 8.School Environment which will influence the personality development of the pupils, 9. Preparing pupils for getting a job.

Furthermore, teachers were asked to respond to a statement about the role of their School Principal on effective school management.

The distributed questionnaire has been previously validated and used for research purposes in Greece (Aygeros, 2009). Data collected were analysed using the Statistical Package for Social Sciences (SPSS) and the effect of age and work experience was investigated using ANOVA followed by Bonferroni's post-hoc comparisons tests.

\section{Results \& Discussion}

A total of 165 Secondary Education teachers completed the anonymous survey. The demographic data of the participants are presented in Tables 1-3.

The sample included 165 teachers: a small percentage of them were younger than 40 years old (15.8\%) while the majority were between $40-60$ years old and a small fraction (5.5\%) were older than 61 years old. All participants had teaching experience ranging from $10-25$ years to over 30 years of experience, while almost $1 / 3$ hold a post graduate degree $(27,2 \%)$.

Table 1: Age groups of the teachers who participated in the present study

\begin{tabular}{|c|c|c|}
\hline Age group & Count & Percent \% \\
\hline $30-40$ & 26 & 15.8 \\
$41-50$ & 61 & 37.0 \\
$51-60$ & 69 & 41.8 \\
$>61$ & 9 & 5.5 \\
Total & 165 & 100.0 \\
\hline
\end{tabular}

Table 2: Teaching experience of the participants in the present study

\begin{tabular}{ccc}
\hline Teaching experience (years) & Count & Percent \% \\
$>10$ & 0 & 0.00 \\
$10-15$ & 44 & 26.7 \\
$16-20$ & 43 & 26.1 \\
$21-25$ & 35 & 21.2 \\
$26-30$ & 24 & 14.5 \\
$>30$ & 19 & 11.5 \\
Total & 165 & 100.0 \\
\hline
\end{tabular}


Table 3: Qualifications of the participants in the present study

\begin{tabular}{|c|c|c|}
\hline Academic Qualifications & Count & Percent \% \\
\hline $1^{\text {st }}$ degree & 106 & 64.2 \\
Additional 1 ${ }^{\text {st }}$ degree & 14 & 8.5 \\
Master & 40 & 24.2 \\
PhD & 5 & 3.0 \\
Total & 165 & 100.0 \\
\hline
\end{tabular}

Most of the teachers (63.03\%) expressed their views on the significant role of their school leader in improving the effectiveness of their educational unit.

Their views on the priorities of effective school management included: collaboration with their Principal, parents, pupils and teachers' job satisfaction. More specifically, as most favourable priority was indicated the teamwork and collaboration with their Principal and pupils, teachers' job satisfaction (39,39\%), parental involvement and collaboration (33,33\%) whereas the least selected priority (26\% of the participants replied with Strongly agree) was helping pupils get a job (Table 4).

Table 4. Teachers' ( $n=165)$ views for the Priorities of Effective School Management

\begin{tabular}{|c|c|c|c|c|c|}
\hline $\begin{array}{l}\text { Teachers' views for } \\
\text { the Priorities of Effective School } \\
\text { Management }\end{array}$ & $\begin{array}{l}\text { Strongly } \\
\text { disagree } \\
(\%)\end{array}$ & $\begin{array}{l}\text { Somewhat } \\
\text { disagree } \\
\text { (\%) }\end{array}$ & $\begin{array}{l}\text { Neither agree } \\
\text { nor disagree } \\
(\%)\end{array}$ & $\begin{array}{l}\text { Agree } \\
(\%)\end{array}$ & $\begin{array}{l}\text { Strongly } \\
\text { agree } \\
(\%)\end{array}$ \\
\hline Pupils' Academic Performance & 0.0 & 4.24 & 27.88 & $39 \cdot 34$ & 28.45 \\
\hline $\begin{array}{l}\text { Encourage innovative teaching } \\
\text { approaches }\end{array}$ & 5.45 & 10.91 & 21.82 & 40.61 & 21.21 \\
\hline $\begin{array}{l}\text { Raise teachers' aspirations for all of } \\
\text { their pupils }\end{array}$ & 1.21 & 7.88 & 22.42 & 47.88 & 20.61 \\
\hline Teachers' Job satisfaction & 1.21 & 6.67 & 22.42 & 30.30 & 39.39 \\
\hline $\begin{array}{l}\text { Teachers' team work - collaboration } \\
\text { with their Principal }\end{array}$ & 1.21 & 3.03 & 10.30 & 29.09 & 56.36 \\
\hline Collaboration with pupils & 0.0 & 3.03 & 8.48 & 32.12 & 56.36 \\
\hline $\begin{array}{l}\text { Parental involvement-collaboration } \\
\text { between teachers and parents }\end{array}$ & 2.42 & 8.48 & 14.55 & 41.21 & 33.33 \\
\hline $\begin{array}{l}\text { School environment which will } \\
\text { influence the personality } \\
\text { development of pupils }\end{array}$ & 0.0 & 0.61 & 5.45 & 7.88 & 26.67 \\
\hline Preparing pupils for getting a job & 4.85 & 16.97 & 24.85 & 29.09 & 24.24 \\
\hline
\end{tabular}

Some differences were observed in teachers' views according to age and work experience: for example, younger and less experienced teachers gave higher priorities in pupils' academic performance and teachers' team work and collaboration with the Principal, compared to older or more experienced teachers (Table 5).

Table 5. Teachers' age and views on the priorities Effective School Management

\begin{tabular}{lccc}
\hline $\begin{array}{l}\text { Teachers' views for the Priorities of } \\
\text { Effective School Management }\end{array}$ & $\begin{array}{c}\text { Age } \\
\text { Groups }\end{array}$ & $\begin{array}{c}\text { Average score } \\
( \pm \mathbf{s d})\end{array}$ & $\begin{array}{c}\text { One-way ANOVA followed by } \\
\text { Bonferroni's post-hoc } \\
\text { comparisons tests }\end{array}$ \\
\hline Pupils' Academic Performance & $30-40 \mathrm{a}$ & $4.19(0.69)$ & \\
& $41-50 \mathrm{a}$ & $4.07(0.89)$ & $p=0.033$ \\
& $51-6 \mathrm{ob}$ & $3.71(0.86)$ & \\
& $>61 \mathrm{~b}$ & $3.78(0.67)$ & \\
\hline
\end{tabular}




\begin{tabular}{|c|c|c|c|}
\hline $\begin{array}{l}\text { Teachers' views for the Priorities of } \\
\text { Effective School Management }\end{array}$ & $\begin{array}{l}\text { Age } \\
\text { Groups }\end{array}$ & $\begin{array}{l}\text { Average score } \\
\qquad( \pm \mathrm{sd})\end{array}$ & $\begin{array}{l}\text { One-way ANOVA followed by } \\
\text { Bonferroni's post-hoc } \\
\text { comparisons tests }\end{array}$ \\
\hline \multirow{4}{*}{$\begin{array}{l}\text { Employing innovative } \\
\text { teaching approaches }\end{array}$} & $30-40$ & $3.81(0.75)$ & \multirow[t]{4}{*}{ ( } \\
\hline & $41-50$ & $3.67(1.04)$ & \\
\hline & $51-60$ & $3 \cdot 57(1.21)$ & \\
\hline & $>61$ & $3.00(1.41)$ & \\
\hline \multirow{4}{*}{$\begin{array}{l}\text { Raise teachers' aspirations for all of their } \\
\text { pupils }\end{array}$} & $30-40 \mathrm{a}$ & $4.12(0.59)$ & \multirow{4}{*}{$p=0.029$} \\
\hline & 41-50 & $3.72(0.93)$ & \\
\hline & $51-6 o b$ & $3.67(0.95)$ & \\
\hline & $>61$ & $4.22(0.83)$ & \\
\hline \multirow[t]{4}{*}{ Teachers' Job satisfaction } & $30-40$ & $4.27(0.87)$ & \multirow{4}{*}{$N S$} \\
\hline & $41-50$ & $4.11(0.98)$ & \\
\hline & $51-60$ & 3.86(1.03) & \\
\hline & $>61$ & $3 \cdot 56(1.01)$ & \\
\hline \multirow{4}{*}{$\begin{array}{l}\text { Teachers' team work- collaboration with their } \\
\text { Principal }\end{array}$} & $30-40 \mathrm{a}$ & $4.69(0.47)$ & \multirow{4}{*}{$p=0.01$} \\
\hline & $41-50$ & $4.49(0.72)$ & \\
\hline & $51-6 o b$ & $4.26(0.92)$ & \\
\hline & $>61$ & $3.33(1.50)$ & \\
\hline \multirow[t]{4}{*}{ Collaboration with pupils } & $30-40$ & $4.65(0.49)$ & \multirow{4}{*}{$N S$} \\
\hline & $41-50$ & $4.46(0.72)$ & \\
\hline & $51-60$ & $4.33(0.87)$ & \\
\hline & $>61$ & $4.11(0.93)$ & \\
\hline \multirow{4}{*}{$\begin{array}{l}\text { Parental involvement-collaboration between } \\
\text { teachers and parents }\end{array}$} & $30-40$ & $4.15(0.61)$ & \multirow{4}{*}{$N S$} \\
\hline & $41-50$ & $4.03(1.03)$ & \\
\hline & $51-60$ & $3.90(1.07)$ & \\
\hline & $>61$ & $3.11(1.17)$ & \\
\hline \multirow{4}{*}{$\begin{array}{l}\text { School environment which will influence the } \\
\text { personality development of pupils }\end{array}$} & $30-40$ a & $4.73(0.53)$ & \multirow{4}{*}{$p=0.018$} \\
\hline & $41-50$ & $4.44(0.85)$ & \\
\hline & $51-6 o b$ & $4.28(1.01)$ & \\
\hline & $>61$ & $3.89(0.78)$ & \\
\hline \multirow[t]{4}{*}{ Preparing pupils getting a job } & $30-40$ & $3.69(1.12)$ & \multirow{4}{*}{ NS } \\
\hline & $41-50$ & $3 \cdot 52(1.12)$ & \\
\hline & $51-60$ & $3.41(1.30)$ & \\
\hline & $>61$ & $3.67(0.50)$ & \\
\hline
\end{tabular}

An analysis (ANOVA) of the results indicated that teachers' views did not vary according to gender or level of academic qualifications (results not shown).

In contrast, there was a significant difference in their views according to their work experience and most specifically regarding the need for raising teachers' aspirations for all of their pupils/students and focusing on teaching staff's job satisfaction (Table 4, Table 6).

TABLE 6. The effect of work experience on teachers' views for Effective School Management priorities

\begin{tabular}{lccc}
\hline Priorities & $\begin{array}{c}\text { Years of Work } \\
\text { Experience }\end{array}$ & $\begin{array}{c}\text { Average } \\
\text { score } \\
( \pm \mathbf{s d})\end{array}$ & $\begin{array}{c}\text { One-way ANOVA followed by } \\
\text { Bonferroni's post-hoc } \\
\text { comparisons }\end{array}$ \\
\hline Students' Academic Performance & $10-15 \mathrm{a}$ & $4.18(0.87)$ & \\
$16-20$ & $4.07(0.83)$ & $\mathrm{p}=0.035$ \\
$21-25 \mathrm{~b}$ & $3.66(0.97)$ & \\
$26-30$ & $3.79(0.72)$ & \\
$730 \mathrm{~b}$ & $3.63(0.63)$ & \\
\hline
\end{tabular}




\begin{tabular}{|c|c|c|c|}
\hline Priorities & $\begin{array}{l}\text { Years of Work } \\
\text { Experience }\end{array}$ & $\begin{array}{c}\text { Average } \\
\text { score } \\
( \pm \mathbf{s d}) \\
\end{array}$ & $\begin{array}{c}\text { One-way ANOVA followed by } \\
\text { Bonferroni's post-hoc } \\
\text { comparisons }\end{array}$ \\
\hline \multirow{5}{*}{$\begin{array}{l}\text { Encourage innovative teaching } \\
\text { approaches }\end{array}$} & $10-15$ & $3.89(0.75)$ & \multirow{5}{*}{ NS } \\
\hline & $16-20$ & $3.79(0.99)$ & \\
\hline & $21-25$ & $3.43(1.33)$ & \\
\hline & $26-30$ & $3.42(1.21)$ & \\
\hline & $>30$ & $3.16(1.26)$ & \\
\hline \multirow{5}{*}{$\begin{array}{l}\text { Raise teachers' aspirations for all of } \\
\text { their pupils }\end{array}$} & $10-15 a$ & $4.02(0.55)$ & \multirow{5}{*}{$\mathrm{p}=0.044$} \\
\hline & $16-20$ & $3.81(1.05)$ & \\
\hline & $21-25 b$ & $3.63(0.84)$ & \\
\hline & $26-3 \mathrm{ob}$ & $3.42(1.06)$ & \\
\hline & $>30$ & $3.95(0.97)$ & \\
\hline \multirow[t]{5}{*}{ Teachers' Job satisfaction } & $10-15 a$ & $4 \cdot 30(0.85)$ & \multirow{5}{*}{$\mathrm{p}=0.005$} \\
\hline & $16-20$ & $4.26(1.00)$ & \\
\hline & $21-25$ & $3.71(1.02)$ & \\
\hline & $26-30$ & $3.75(1.03)$ & \\
\hline & $>30 \mathrm{~b}$ & $3.58(0.96)$ & \\
\hline \multirow{5}{*}{$\begin{array}{l}\text { Teachers' team work- collaboration } \\
\text { with the Principal }\end{array}$} & $10-15 \mathrm{a}$ & $4.73(0.45)$ & \multirow{5}{*}{$\mathrm{p}<0.001$} \\
\hline & $16-20$ & $4.53(0.70)$ & \\
\hline & $21-25$ & $4.26(0.89)$ & \\
\hline & $26-30$ & $4.21(0.83)$ & \\
\hline & $>30 \mathrm{~b}$ & $3.53(1.35)$ & \\
\hline \multirow[t]{5}{*}{ Collaboration with pupils } & $10-15 a$ & $4.66(0.48)$ & \multirow{5}{*}{$\mathrm{p}=0.028$} \\
\hline & $16-20$ & $4.51(0.74)$ & \\
\hline & $21-25$ & $4.23(0.97)$ & \\
\hline & $26-30 b$ & $4.17(0.76)$ & \\
\hline & $>30$ & $4 \cdot 32(0.89)$ & \\
\hline \multirow{5}{*}{$\begin{array}{l}\text { Parental involvement-collaboration } \\
\text { between teachers and parents }\end{array}$} & $10-15$ & $4.14(0.80)$ & \multirow{5}{*}{ NS } \\
\hline & $16-20$ & $4.12(0.91)$ & \\
\hline & $21-25$ & $3.71(1.27)$ & \\
\hline & $26-30$ & $4.00(0.88)$ & \\
\hline & $>30$ & $3.47(1.22)$ & \\
\hline \multirow{5}{*}{$\begin{array}{l}\text { School environment which will } \\
\text { influence the personality development } \\
\text { of pupils }\end{array}$} & $10-15$ & $4.61(0.62)$ & \multirow{5}{*}{ NS } \\
\hline & $16-20$ & $4.53(0.77)$ & \\
\hline & $21-25$ & $4.17(1.15)$ & \\
\hline & $26-30$ & $4.17(1.01)$ & \\
\hline & $>30$ & $4.21(0.92)$ & \\
\hline \multirow[t]{5}{*}{ Preparing pupils for getting a job } & $10-15$ & $3 \cdot 57(1.15)$ & \multirow{5}{*}{ NS } \\
\hline & $16-20$ & $3.51(1.05)$ & \\
\hline & $21-25$ & $3 \cdot 37(1.44)$ & \\
\hline & $26-30$ & $3.50(1.32)$ & \\
\hline & $>30$ & $3.63(0.76)$ & \\
\hline
\end{tabular}

Compared to Public Schools, teachers working in Private Schools gave increased priority on: pupils' academic performance; raise teachers' aspirations for all of their pupils; teachers' job satisfaction; teachers' team work and collaboration with the Principal; parental involvement-collaboration between teachers and parents and school environment which will influence the personality development of pupils (Table 7). 
Table 7. Comparison between Public and Private School teachers on their views of effective School management priorities

\begin{tabular}{lccc}
\hline $\begin{array}{l}\text { Teachers' views for the priorities of effective School } \\
\text { Management }\end{array}$ & $\begin{array}{c}\text { Public } \\
\text { School } \\
(\mathbf{n = 1 3 3})\end{array}$ & $\begin{array}{c}\text { Private } \\
\text { School } \\
(\mathbf{n = 3 2})\end{array}$ & $\begin{array}{c}\text { Mann-Whitney } \\
\text { test }\end{array}$ \\
\hline Pupils' Academic Performance & $3.79(0.84)$ & $4.45(0.71)$ & $\mathrm{P}<0.01$ \\
Employing innovative approaches in teaching & $3.58(1.19)$ & $3.76(0.61)$ & $\mathrm{NS}$ \\
Raise Teachers aspirations for all of their pupils & $3.71(0.97)$ & $4.09(0.46)$ & $\mathrm{P}<0.01$ \\
Teachers' Job satisfaction & $3.89(1.03)$ & $4.45(0.71)$ & $\mathrm{P}<0.001$ \\
Teachers' team work - collaboration with the Principal & $4.30(0.94)$ & $4.64(0.49)$ & $\mathrm{P}=0.005$ \\
Collaboration with pupils & $4.38(0.82)$ & $4.58(0.50)$ & $\mathrm{NS}$ \\
Parental involvement-collaboration between teachers and parents & $3.86(1.08)$ & $4.27(0.67)$ & $\mathrm{P}-0.08$ \\
School environment which will influence the personality & $4.30(0.96)$ & $4.76(0.44)$ & $\mathrm{P}<0.01$ \\
development of pupils & $3.5(1.19)$ & $3.55(1.12)$ & $\mathrm{NS}$ \\
Preparing pupils for getting a job & & &
\end{tabular}

To facilitate comparison between the rank of priorities of Private and Public school teachers, the score of the answers on each priority was transformed on a scale of 1-10. The priorities were ranked according to the sequence of their score and the results were plotted according to the rank of each priority (Figure 1).

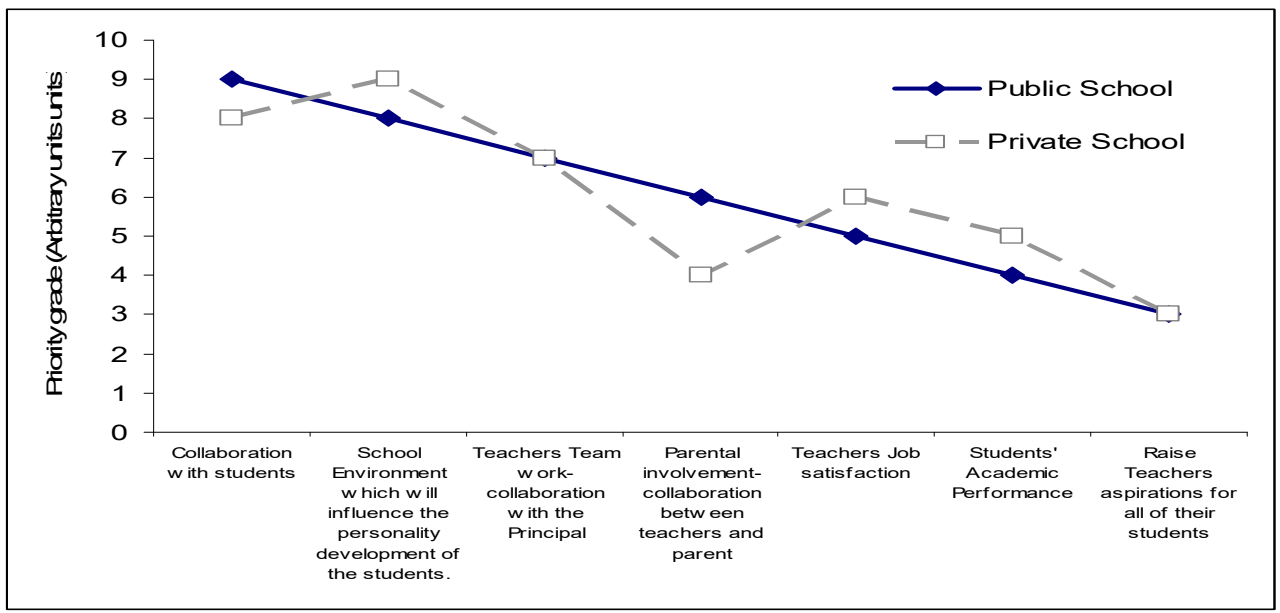

Figure 1. Top-seven of teachers' priorities (Arbitrary units) for effective school management in Public (solid line) and Private (dashed line) schools

The results indicate that there were minor differences on the top-seven priorities for effective school management in Public and Private schools. In fact, teachers of both Public and Private schools gave the highest priority on: the collaboration with pupils and teachers, team work and collaboration with their Principal and low priority on: employing innovative approaches in teaching and preparing pupils for getting a job.

\section{Conclusion}

The results of the present work confirm the established notion that teachers give great value on school principal's role for effective management of their educational unit (Hallinger \& Heck, 1998). A 
school leader is expected to take a leading role in identifying and shaping the policies which will serve the goals of a school unit. Teachers' perceptions and priorities for school goals will be equally influenced by school leadership (Skaalvik \& Skaalvik, 2013).

Researchers, policy makers and school principals frequently explore several methods to evaluate school leadership, school effectiveness and possible initiatives which can be employed to enhance school outcomes.

Teachers' views on the priorities and policies of their school is a significant element of effective human resources management (Skaalvik \& Skaalvik, 2017).

Understanding what teachers believe about their Principal's contribution, the needs and priorities of their school unit is a practical problem. In this quest for answers lays the difficulty in decision making process and setting the goals of effectiveness or the educational goals of each school unit. Different schools may be facing different problems needs and priorities as a result of several various external and internal variables (Oreopoulos, 2012; Wodtke \& Parbst, 2016).

Teachers' expectations for their school leaders exhibited in the present work are in agreement with previously reported views regarding teachers' expectations on the important role of school leaders in creating a working environment that enhance collaboration with the local community (Anastasiou \& Papakonstantinou, 2015). Teachers' aspirations can vary according to social and economic variables, all affecting and co-shaping what can be viewed as important (Stewart et al., 2007).

The results presented in this study exhibit the significance of age and work experience on shaping teachers' views and priorities on effective school management. Younger and less experienced teachers appeared more decisive on raising the academic performance of their pupils.

This demographic variability may reflect deeper variabilities on teachers' views. Younger teachers may have different educational and personal background, motivations, perceptions and aspirations for their role as teachers (Younger et al., 2004; Watt \& Richardson, 2008). Teaching experience may shape or reshape teachers' views on what is important for their efficacy (Wolters et al., 2007; Zee \& Koomen 2016) with considerable consequences on pupils' teaching and academic performance.

This variability highlights the importance on focusing on teachers' attitudes for successful human resources and effective school management. This is even more important in the case of the Greek educational system which is characterised by a centralised and bureaucratic system in decision making where important decisions like school curricula, textbooks, teachers' appointments, salaries and promotion are taken by the Ministry of Education and uniformly implemented into all schools (Anastasiou \& Papakostantinou, 2014).

\section{References}

Anastasiou, S., \& Papakonstantinou, G. (2014). Factors affecting job satisfaction, stress and work performance of secondary education teachers in Epirus, NW Greece. International Journal of Management in Education, 8(1), 37-53.

Anastasiou, S., \& Papakonstantinou, G. (2015). Greek high school teachers' views on principals' duties, activities and skills of effective school principals supporting and improving education. International Journal of Management in Education, 9(3), 340-358.

Aparicio, J., López-Torres, L., \& Santín, D. (2018). Economic crisis and public education. A productivity analysis using a Hicks-Moorsteen index. Economic Modelling, 71, 34-44.

Aygeros, S. (2009). Effective Principals and secondary education schools. A critical theoretical view on the selection-evaluation and role of Principals. MA dissertation. Hellenic Open University, Patras, Greece. https://apothesis.eap.gr/handle/repo/19148.

Benavot, A. (2015). Literacy in the 21st century: Towards a dynamic nexus of social relations. International Review of Education, 61(3), 273-294. 
Broström, S., A. Sandberg, I. Johansson, K. Margetts, B. Nyland, T. Frøkjær, C. Kieferle, A. Seifert, A. Roth, \& Ugaste, A. (2015). Preschool Teachers Views on Children's Learning: An International Perspective. Early Child Development and Care, 185(5), 824-847.

Creemers, B., \& Kyriakides, L. (2007). The dynamics of educational effectiveness: A contribution to policy, practice and theory in contemporary schools. London:Routledge.

Dahiru, A. S., Pihie, Z. A. L., Basri, R., \& Hassan, S. A. (2017). Mediating effect of teacher empowerment between entrepreneurial leadership and school effectiveness. The Social Sciences, 12(11), 2077-2084.

DeAngelis, C. A. (2018). Does choice matter for school choice? An instrumental variables analysis of the effect of choice on parental satisfaction in charter schools. Journal of School Choice, 12(2), 216-236.

Dimopoulos, K., Dalkavouki, K., \& Koulaidis, V. (2015). Job realities of primary school principals in Greece: similarities and variations in a highly centralized system. International Journal of Leadership in Education, 18(2), 197-224.

Dös, I., \& Savas, A. C. (2015). Elementary School Administrators and Their Roles in the Context of Effective Schools. SAGE Open, 5(1), n1.

Edmonds, R. R. (1979). Some schools work and more can. Social policy, 9(5), 28-32.

Emo, W. (2015). Teachers' motivations for initiating innovations. Journal of Educational Change, 16(2), $171-195$.

Fetters, M. K., Czerniak, C. M., Fish, L., \& Shawberry, J. (2002). Confronting, challenging and changing teachers' beliefs: Implications from a local systemic change professional development program. Journal of science teacher education,13(2), 101-130.

Freeman, J., \& Simonsen, B. (2015). Examining the impact of policy and practice interventions on high school dropout and school completion rates: A systematic review of the literature. Review of Educational Research, $85(2), 205-248$.

Gill, M. G., Ashton, P., \& Algina, J. (2004). Authoritative schools: A test of a model to resolve the school effectiveness debate. Contemporary Educational Psychology, 29(4), 389-409.

Gunawan, S., \& Shieh, C. J. (2016). A study on the effects of knowledge share in virtual community on creative teaching behaviours and teacher efficacy. Eurasia Journal of Mathematics, Science E Technology Education, $12(4), 1101-1113$.

Hallinger, P., \& Heck, R. H. (1998). Exploring the principal's contribution to school effectiveness: 1980-1995. School effectiveness and school improvement, 9(2), 157-191.

Koutouzis, M., \& Malliara, K. (2017). Teachers' Job Satisfaction: The Effect of Principal's Leadership and DecisionMaking Style. International Journal of Education, 9(4), 71-89.

Levin, H. M., \& Belfield, C. (2015). Guiding the development and use of cost-effectiveness analysis in education. Journal of Research on Educational Effectiveness, 8(3), 400-418.

Li, L., Hallinger, P., \& Ko, J. (2016). Principal leadership and school capacity effects on teacher learning in Hong Kong. International Journal of Educational Management, 30(1), 76-100.

Morrissey, T. W., \& Vinopal, K. (2018). Centre-based early care and education and children's school readiness: Do impacts vary by neighbourhood poverty? Developmental psychology, 54(4), 757.

Moss, G. (2017). Assessment, accountability and the literacy curriculum: reimagining the future in the light of the past. Literacy, 51(2), 56-64.

Nathanaili, V. (2016). Teacher's Influence Scale from Their Colleagues and Principals: Its Relation with School Performance in Public Schools of the Albanian Educational System. IAFOR Journal of Education, 4(1), 106121.

Oreopoulos, P. (2012). Moving Neighbourhoods Versus Reforming Schools: A Canadian's Perspective. Cityscape, 207-212.

Rawolle, S., Wells, M., Paatsch, L., Tytler, R., \& Campbell, C. (2016). School improvement as a global movement. In, S. Rawolle, M. Wells, L. Paatsch, Tytler, R. \& C. Campbell (eds) Improving Schools. Productive Tensions between the Local, the Systemic and the Global (pp.1-

24). Springer: Singapore.

Rutter, M., \& Maughan, B. (2002). School effectiveness findings 1979-2002. Journal of school psychology, 40(6), 451-475.

Skaalvik, E.M. \& Skaalvik, S. (2013). Teachers' perceptions of the school goal structure: Relations with teachers' goal orientations, work engagement, and job satisfaction. International Journal of Educational Research, 62(3), 199-209,

Skaalvik, E. M., \& Skaalvik, S. (2017). Motivated for teaching? Associations with school goal structure, teacher selfefficacy, job satisfaction and emotional exhaustion. Teaching and Teacher Education, 67, 152-16o. 


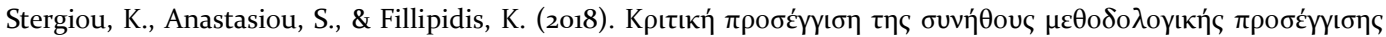

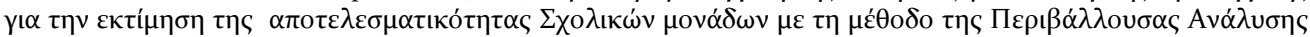

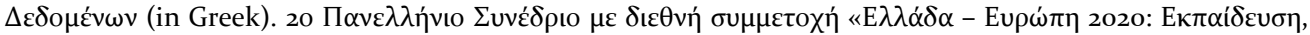

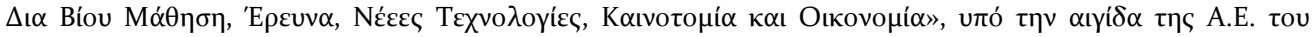

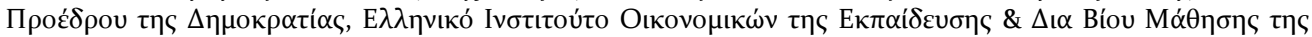

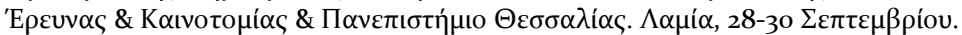

Stewart, E. B., Stewart, E. A., \& Simons, R. L. (2007). The effect of neighbourhood context on the college aspirations of African American adolescents. American Educational Research Journal, 44(4), 896-919.

Taştan, S. B., Davoudi, S. M. M., Masalimova, A. R., Bersanov, A. S., Kurbanov, R. A., Boiarchuk, A. V., \& Pavlushin, A. A. (2018). The impacts of teacher's efficacy and motivation on student's academic achievement in science education among secondary and high school students. EURASIA Journal of Mathematics Science and Technology Education, 14(6), 2353-2366.

Wajdi, M. B. N., Rahayu, S., Ulfatin, N., Wiyono, B. B., \& Imron, A. (2018). The professional competency teachers mediate the influence of teacher innovation and emotional intelligence on school security. Journal of Social Studies Education Research, 9(2), 210-227.

Warren, J. M., Locklear, L. A., \& Watson, N. A. (2018). The Role of Parenting in Predicting Student Achievement: Considerations for School Counselling Practice and Research. Professional Counselor, 8(4), 328-340.

Watt, H. M., \& Richardson, P. W. (2008). Motivations, perceptions, and aspirations concerning teaching as a career for different types of beginning teachers. Learning and instruction, 18(5), 408-428.

Wodtke, G. T., \& Parbst, M. (2016). Does School Poverty Mediate the Effects of Neighbourhood Context on Academic Achievement During Childhood? University of Toronto Sociology Working Paper (2016-01).

Wolters, C. A., \& Daugherty, S. G. (2007). Goal structures and teachers' sense of efficacy: Their relation and association to teaching experience and academic level. Journal of educational psychology, 99(1), 181.

Younger, M., Brindley, S., Pedder, D., \& Hagger, H. (2004). Starting points: student teachers' reasons for becoming teachers and their preconceptions of what this will mean. European Journal of Teacher Education, 27(3), 245264.

Zee, M., \& Koomen, H. M. (2016). Teacher self-efficacy and its effects on classroom processes, student academic adjustment, and teacher well-being: A synthesis of 40 years of research. Review of Educational research, 86(4), 981-1015. 